\title{
KARL MARX E A DOUTRINA SOCIAL DA IGREJA: RELAÇÕES E DIFERENÇAS FUNDAMENTAIS
}

\author{
Karl Marx and the Church's Social Doctrine: relationships and fundamental \\ differences
}

Élio Gasda *

Resumo: Catolicismo e Marxismo são tão antagônicos assim? Existe algum elemento em comum? Esse debate vem ocupando historiadores e acadêmicos desde a publicação de Rerum Novarum e do pensamento de Karl Marx, que irrompem como reação à Revolução industrial conduzida pela economia de mercado do capitalismo. $\mathrm{O}$ artigo descreve, primeiramente, seus pontos de contato: origem cronológica e motivação comum; a exploração do proletariado e a centralidade do trabalho humano. Em seguida, expõe as duas diferenças fundamentais: o marxismo como teoria crítica da economia política e a Doutrina social da Igreja como teologia moral. Quanto ao objetivo: em Marx é alcançar a sociedade comunista sem classes. $O$ objetivo da DSI é auxiliar os cristãos a viver a esperança no Reino de Deus, antecipando sua realidade em sinais concretos na história. Em terceiro lugar, o texto aborda os recentes sinais de aproximação entre os dois. Marxismo e Doutrina Social da Igreja continuam atuais.

Palavras-chave: Karl Marx. Doutrina Social da Igreja. Socialismo. Capitalismo. Trabalho.

Abstract: Are Catholicism and Marxism really so antagonistic? Do they have any elements in common? This debate has been occupying historians and academics since the publication of Rerum Novarum and Karl Mark's thought, which appear as a reaction to the industrial revolution driven by capitalism and the market

\footnotetext{
* Doutor em Teologia pela Universidad Pontificia Comillas (Espanha), professor do Departamento de Teologia da Faculdade Jesuíta de Filosofia e Teologia, Belo Horizonte, MG. Artigo recebido em 05/08/2019 e aprovado para publicação em 15/09/2019.
} 
economy). The article first describes their points of contact: chronological origin and their common motivation, that is, the exploitation of the proletariat and the centrality of human work. It then exposes the two fundamental differences: Marxism as a critical theory of political economics and the Church's Social Doctrine as moral theology. Marx's goal is to achieve a communist society without classes, whereas the goal of the Church's Social Doctrine is to help Christians to live in the hope of the Kingdom of God, anticipating its reality through the concrete signs of history. Third, the text addresses the recent signs of approximation between the two, since both Marxism and the Church's Social Doctrine remain timely.

Keywords: Karl Marx. Church Social Doctrine. Socialism. Capitalism. Work.

\section{Estado da questão}

$\mathrm{P}$ erguntar pelas diferenças entre o pensamento de Karl Marx e a Doutrina Social da Igreja é retórico. Marx considera todo discurso religioso como categoria de um princípio ideológico. Entretanto, é possível encontrar suas relações com um corpo teórico produzido por uma religião? "A crítica da religião é a condição preliminar, o pressuposto de toda a crítica. O homem faz a religião, a religião não faz o homem. O homem é o mundo do homem, o Estado, a sociedade. Esse Estado e essa sociedade produzem a religião, uma consciência invertida do mundo, porque eles são um mundo invertido"1. A religião é uma expressão às avessas das condições inumanas em que o homem se encontra, é um protesto impotente contra o sofrimento que o impede de tomar consciência da realidade. A religião funciona como uma espécie de "ópio" que adormece a consciência popular. Seu véu esconde a política e o Estado que oculta a exploração humana.

As relações parecem inconcebíveis para marxistas e cristãos. Mas eis que surge Papa Francisco, que já em seu primeiro documento, foi contundente: "não a uma economia da exclusão e da desigualdade! Essa economia mata" (EG, 53). ${ }^{2}$ Em outro pronunciamento foi ainda mais incisivo: "Esse sistema é terrorista. Quem governa? O dinheiro. Como governa? Com o chicote do medo, da desigualdade, da violência econômica, social, cultural e militar que gera mais violência em uma espiral que não acaba nunca. Há um terrorismo de base que emana do controle global do dinheiro sobre a terra e ameaça toda a humanidade. Esse sistema

\footnotetext{
${ }^{1}$ MARX, Karl. Crítica da Filosofia do Direito de Hegel. São Paulo: Boitempo, 2013, p. 151.

${ }^{2}$ FRANCISCO, Papa. Exortação Apostólica Evangelii Gaudium (EG). Roma: Libreria Editrice Vaticana, 2013.
} 
tiraniza e aterroriza a humanidade" ${ }^{\prime 3}$. Imediatamente foi acusado de comunista, de marxista. Em entrevista à imprensa, ponderou: "Eu digo que os comunistas roubaram a nossa bandeira. A bandeira dos pobres é cristã. A pobreza está no centro do Evangelho. Os comunistas dizem que tudo é comunista. Sei, sei, vinte séculos depois. Então, quando eles falam, poderíamos dizer: então vocês são cristãos" ${ }^{4}$. Também Paulo VI foi chamado de comunista quando publicou a encíclica social Populorum Progressio (1967). Vale lembrar a conhecida sentença de Dom Helder Câmara: "Quando dou comida aos pobres, me chamam de santo. Mas quando pergunto por que razão os pobres não têm comida, me chamam de comunista."

A questão das relações e diferenças entre cristãos e marxistas tem despertado o interesse de diversos autores. A modo de ilustração vale citar: Martin D'Arcy. Comunismo e Cristianismo (Rio de Janeiro, 1959); Georges Cottier. Esperanzas enfrentadas: cristianismo y marxismo (Bogotá, 1975); Roger Garaudy. Do anátema ao diálogo: um marxista se dirige ao Concílio (Rio de Janeiro, 1966); Jean Kanapa. La Doctrine Sociale de l'Eglise et le marxisme (Paris, 1962); Jean Ives-Calvez. O pensamento de Karl Marx (Porto, 1959). Na esfera ibero-americana, é conhecido o polêmico debate entre dois jesuítas: Enrique M. Urena, com seu El mito del cristianismo socialista. (Madrid, 1980), prontamente contestado por José Ignacio González Faus, com El engaño de un capitalismo aceptable (Santander, 1983). No Brasil a questão foi abordada por outro jesuíta e filósofo, Henrique de Lima Vaz: Marxismo e filosofia (Síntese, 959, 2, pg. 46-64), e Marx e o Cristianismo (Perspectiva Teológica, v. $15,37,1983$, pp. 351-364).

O presente artigo aborda as relações e diferenças fundamentais da Doutrina Social da Igreja (DSI) em comparação com o pensamento de Kal Marx, não com as interpretações de seus sucessores reunidos em torno da vasta tradição marxista e sua pluralidade de correntes. O método é a consulta imediata às fontes. O artigo está organizado em três partes e uma conclusão: 1. Identificação dos principais pontos de contato entre marxismo e DSI; 2. Apresentação das diferenças fundamentais; 3. Do confronto aos canais de diálogo: situação atual.

\footnotetext{
${ }^{3}$ FRANCISCO, Papa. III Encontro Mundial dos movimentos populares. Disponível em:<. http://w2.vatican.va/content/francesco/pt/speeches/2016/november/documents/papa-francesco_20161105_movimenti-popolari.html>. Acesso em: 15/38/2019. Em continuação: III Encontro

${ }^{4}$ GIANSOLDATI, Franca. Jornal Il Messaggero, Roma, 29-06-2014. Tradução Moisés Sbardelotto. Disponível em: <http://www.ihu.unisinos.br/noticias/532796-o-comunismo-nos-roubou-a-bandeira-entrevista-com-o-papa-francisco>. Acesso em 18/03/2019.
} 


\section{Relações}

\section{De origem: Revolução Industrial}

A DSI e a o pensamento de Karl Marx são contemporâneos. De surgimento simultâneo, de contexto e preocupação semelhantes: a condição dos operários. O trabalho está no centro das profundas transformações causadas pela economia moderna capitalista que irrompe no século XVIII. Os novos intelectuais-economistas exaltam o trabalho como o meio ideal para a prosperidade. John Locke (1632-1704) vê no trabalho a origem da propriedade privada. ${ }^{5}$ Adam Smith (1723-1790) o considera como principal fator de riqueza material das nações. ${ }^{6}$

A organização do trabalho é alterada em sincronia com a organização do sistema de mercado que, por sua vez, é acompanhado por mudanças na organização da sociedade. ${ }^{7}$ A fábrica tornou-se o lugar por excelência da sociedade. $\mathrm{O}$ trabalho na empresa e a relação salarial estruturam as demais relações. $\mathrm{Na}$ indústria existem dois tipos de homens: empregadores e empregados. ${ }^{8}$ Para R. Castel "a plena aceitação da relação salarial representou uma etapa decisiva na evolução da modernidade: um modelo de sociedade em que posições sociais são essencialmente definidas através do lugar da divisão do trabalho." ${ }^{\prime 9}$

No caso do capitalismo, "toda a economia de mercado é uma economia orientada pelo preço de mercado e só por eles."10 Os preços são fixados pela lei da oferta e da procura. $O$ trabalho convertido em mercadoria gerou a sociedade salarial. $\mathrm{O}$ trabalho é uma atividade que rende produtividade no mercado. A Industrialização criou uma demanda de trabalho que resultou em concentrações humanas desconhecidas na história. Bairros populares com ausência total de segurança, moradias improvisadas em porões abandonados, ausência de escolas, hospitais e outros serviços públicos. ${ }^{11}$ As

\footnotetext{
${ }^{5}$ LOCKE, John. Segundo Tratado del Gobierno Civil (1690). Madrid: Alianza, 1990. Capítulo $\mathrm{V}$ - De la propiedad.

${ }^{6}$ SMITH, Adam. La riqueza de las naciones (1776). Madrid: Aguilar, 1961. Adam Smith estuda o problema da produtividade e o trabalho produtivo no Livro II desta obra, mais especificamente, no terceiro capítulo: Sobre a acumulacção do capital, ou do trabalho produtivo e improdutivo.

${ }^{7}$ Cf. POLANYI, Karl. La gran transformación. Madrid: La Piqueta, 1989, p. 132-133.

${ }^{8}$ PARIAS, Louis-Henri (dir.). Historia general del trabajo. La era de las revoluciones (1760-1914). México: Grijalbo, 1965, p. 48.

${ }^{9}$ Cf. CASTEL, Robert. Las metamorfosis de la cuestión social. Una crónica del salariado. Barcelona: Paidós, 1997, p. 322s.

${ }^{10}$ Ibidem, p. 83.

11 "Os operários se amontoavam em número crescente nas novas cidades industriais". CALVEZ, Jean.-Yves. El pensamiento de Carlos Marx. Madrid: Taurus, 1966, p. 274.
} 
condições tornaram-se mais cruéis. A distância que separava o proletariado "fabricante" do empregador era grande. Um abismo! Para o trabalhador, "a liberdade consiste entre escolher trabalhar ou morrer de fome, entre trabalho remunerado e ou por conta própria; entre um trabalho salariado e outro."12 A industrialização piorou consideravelmente o estatuto dos trabalhadores. A vida do operário é marcada pelo trabalho assalariado.

Neste contexto de prosperidade do capital e a miséria do trabalho, irrompem as figuras de Karl Marx e Leão XIII. Marxismo e Doutrina Social da Igreja são, em certa medida, teorias da revolução industrial. O Manifesto Comunista foi publicado em 1848 e a Rerum Novarum (RN) em 1891.

\section{A questão operária em Karl Marx}

A questão operária ocupa o centro do pensamento de Karl Marx (Trier, 1818-1883). ${ }^{13}$ É ele autor da crítica mais consistente já feita à economia política do capitalismo.

O motor do pleno desenvolvimento humano é o trabalho. "O trabalho livre é a essência do homem."14 Mas o capitalismo é incapaz de promover o humanismo, a liberdade e a emancipação. $\mathrm{O}$ trabalho leva à degradação individual e coletiva e a opressão do homem pelo homem. O operário é tratado como um animal reduzido às suas necessidades físicas naturais. ${ }^{15}$ Nisto consiste a alienação: a corrupção do trabalho e da natureza humana do trabalhador.

Nos Manuscritos ${ }^{16}$, Marx especifica as principais características do trabalho alienado: é uma coisa exterior ao trabalhador. $\mathrm{O}$ homem se renega, é infeliz, não desenvolve suas energias com liberdade, esgotando suas forças espirituais. O operário somente sente-se ele mesmo quando está fora de seu trabalho. No trabalho está estranhado de si. É um trabalho forçado, logo

\footnotetext{
${ }^{12}$ ARENAS POSADAS, C. Historia económica del trabajo: siglos XIX y XX. Madrid: Tecnos, 2003, p. 53.

${ }^{13}$ STEDMAN JONES, Gareth. Karl Marx: Grandeza e ilusão. Tradução de Berilo Vargas. São Paulo: Companhia das Letras, 2017. Marx deixou uma obra com aplicações políticas, econômicas, filosóficas, antropológicas. Manifesto Comunista; Manuscritos econômico-filosóficos; A sagrada família; Crítica da filosofia do direito de Hegel; Sobre o suicídio; A ideologia alemã; Sobre a questão judaica; Lutas de Classes na Alemanha; O 18 de brumário de Luís Bonaparte; A guerra civil na França; Grundrisse (Elementos fundamentais para a crítica da economia política); As lutas de classes na França de 1848 a 1850; Crítica do Programa de Gotha; Lutas de classes na Rússia; O Capital: Crítica da Economia Política. Livro 1: O processo de produção do capital. Livro 2: O processo de circulação do capital; Salário, preço e lucro.

${ }^{14}$ MARX, Karl.; ENGELS, Friedrich. La Ideología Alemana (1845). Barcelona: L’Eina, 1988, p. 12.

${ }^{15}$ MARX, Karl. Manuscritos económicos y filosóficos de 1844. Moscú: Progreso, 1989, p. 22.

${ }^{16}$ Cf. Manuscritos, p. 57-60.
} 
que cessa a coação física ou de outra índole, as pessoas rejeitam o trabalho como se fosse uma peste. $\mathrm{O}$ produto do seu trabalho não lhe pertence. Ele próprio não é dono de si mesmo, pois pertence a outro. É a perda de si mesmo. Trata-se de uma nova forma de escravidão. Há uma mutilação da humanidade do operário, semelhante à dos escravos da antiguidade. $\mathrm{O}$ homem é dominado pelo produto de seu trabalho: devido ao objeto que produz, o operário tem um emprego e os meios de subsistência. Somente na qualidade de trabalhador pode sobreviver como sujeito físico, gastando sua vida em um objeto que lhe domina, e que, uma vez terminado, já não lhe pertence. Homem dominado pelo trabalho: um estranho-desiludido que trabalha em algo que não gosta, pois não é tratado como ser humano. Seu trabalho está controlado pelo dono dos meios de produção, que decide o que produzir, como e para que. Seu trabalho é uma autoflagelação, uma mortificação. Homem alienado em relação ao gênero humano: aquilo que nos caracteriza como seres humanos e que nos faz um ser genérico (membro da espécie humana) é o trabalho. No capitalismo, o trabalhador sente-se livre e ativo somente quando cumpre suas funções animais - comer, beber e procriar - e, no melhor dos casos, construir sua casa e vestir-se. Já em suas funções humanas sente-se um animal. Aquilo que é próprio do animal se converte em destino do homem, e o próprio do humano (o trabalho) se converte em algo animalesco, bestial, desumano. A vida se resume a trabalhar.

A teoria do valor-trabalho ${ }^{17}$ e a propriedade privada dos meios de produção são os dois pilares da alienação. O primeiro é um meio refinado de exploração. O empresário explora da melhor forma possível o produto adquirido (trabalho) para gerar a maior quantidade possível de trabalho. Toda a mais-valia gerada é a base dos ganhos do empresário. O trabalho é uma atividade que busca apenas receber um salário, rebaixando o homem ao nível de mercadoria. ${ }^{18}$ A propriedade privada é a expressão material do trabalho alienado. O capital que transforma o trabalho em mercadoria converte o trabalhador em propriedade de outro. Esta relação hostil com o produto do seu trabalho é transferida para o proprietário. Aqui está a origem da luta de classes. A raiz da divisão de classes é a propriedade privada, resultado do trabalho alienado. ${ }^{19}$ A medida que se acumula o capital necessariamente piora a situação do operário qualquer que seja a sua retribuição. Esta é a lei do princípio da acumulação material. O lucro aumenta na mesma medida em que diminui o salário. O capital tende a concentrar-se em poucas mãos.

\footnotetext{
${ }^{17}$ A crítica da teoria do valor-trabalho e da mais-valia está amplamente exposta na segunda seção de $O$ Capital.

${ }^{18}$ Manuscritos, p. 21. Também: MARX, Karl. Trabajo asalariado y capital. Madrid: R. Aguillera, 1968.

${ }^{19}$ Manuscritos, p. 63-64.
} 
A solução para o conflito está na abolição da propriedade privada e do trabalho como mercadoria. ${ }^{20}$ A supressão da propriedade privada como afirmação da vida humana é a supressão de toda alienação, ou seja, o homem recupera a sua humanidade e sua identidade social. ${ }^{21}$ Portanto, a única solução está na revolução que conduza a uma sociedade socialista como um período de transição - para a sociedade comunista. ${ }^{22}$ No ponto culminante do capítulo 24 de $O$ Capital, dedicado à acumulação primitiva, Marx proclama: "A violência é a parteira de toda velha sociedade que traz uma nova em suas entranhas. Ela mesma é uma potência econômica." ${ }^{23}$

A violência enquanto prática sócio-política, desempenha um papel primordial na história, podendo ser um instrumento por meio do qual se efetiva uma nova ordem social. A violência garante a reprodução ampliada do capital. Portanto, a emancipação dos oprimidos depende da abolição da propriedade privada dos meios de produção através da violência revolucionária. A ação política será violenta pelo fato de que a ordem socioeconômica do capitalismo é sempre violenta. "O comunismo, ao abolir simultaneamente o domínio de classe e a exploração humana, aparece como a superação da propriedade privada, da alienação e, por tanto, como a verdadeira apropriação da essência humana pelo homem e para o homem"24.

\section{A questão operária na DSI}

Muitos católicos se sensibilizaram com as condições de vida miserável da classe operária. Contudo, compartilhavam as ideias e atitudes da burguesia e dos economistas sobre a inevitabilidade das leis econômicas e a fatalidade da condição dos pobres. A mentalidade conservadora, o temor de impor limites ao liberalismo e de aproximar-se do socialismo, evitaram uma postura mais firme em defesa dos operários. Com o surgimento do Catolicismo Social, há um lento processo de amadurecimento da consciência dos católicos. Surgem iniciativas voltadas para aliviar o sofrimento do proletariado: Conferências de S. Vicente de Paulo fundadas por Frederico Ozanam (1833), Pequeno Cotolengo (1827), Escolas profissionalizantes de D. Bosco (1841), Círculos Operários Católicos (1871).

\footnotetext{
${ }^{20}$ La Ideología Alemana, p. 61.

${ }^{21}$ Manuscritos, p. 85. A propriedade privada exerce, em Marx, um papel semelhante ao pecado original para o cristãos.

${ }^{22}$ Manuscritos, p 84.

${ }^{23}$ MARX, Karl. O Capital: crítica da economia política. 2a ed. São Paulo: Nova Cultural, 1985, p. 286.

${ }^{24}$ Manuscritos, p. 84.
} 
O bispo de Mainz, Wilhelm Emmanuel von Ketteler (1811-1877) se destaca como crítico da economia política liberal e defensor dos direitos trabalhistas como a redução da jornada laboral, salário justo e proibição do trabalho infantil. No livro Die Arbeiterfrage und das Christentum (A questão operaria e o cristianismo, 1864), denuncia que não é mais possível ocultar o fato de que a existência da quase totalidade da classe trabalhadora está exposta às oscilações do mercado e dos preços, para a sobrevivência de suas famílias. Vidas expostas dia após dia às eventualidades dos preços de mercado.

As primeiras intervenções do Magistério Pontifício refletem uma mentalidade conservadora: defesa da propriedade e exortação dos pobres à resignação. Os esforços de modificar a situação seriam contrariar a vontade divina. Na encíclica Quod apostolici muneris (1878) Leão XIII argumentava pela incompatibilidade entre a doutrina católica e Marxismo.

Rerum Novarum $(\mathrm{RN})^{25}$, escrita em 1891, primeiro texto oficial da DSI, é a culminação de um processo de tomada de consciência da Igreja ante a miséria dos operários. O documento aborda de forma ampla os problemas derivados da Revolução Industrial e da sociedade de mercado e das grandes transformações provocadas pelo capitalismo. Organizado em torno da chamada «questão operária», o conteúdo denuncia a miséria crescente da classe trabalhadora, se opõe à proposta socialista de transformação radical da sociedade através da abolição da propriedade privada e do trabalho como mercadoria; frente a esta alternativa, a Igreja propõe a manutenção da ordem social vigente, mediante uma estreita colaboração entre a Igreja, o Estado e as classes em conflito.

A RN inicia com uma descrição contundente da miséria e exploração do proletariado fruto da relação trabalho-capital. A nascente DSI reitera a crítica de Marx: "pouco a pouco, os trabalhadores, isolados e sem defesa, têm-se visto, com o decorrer do tempo, entregues à mercê de senhores desumanos e à cobiça de uma concorrência desenfreada. A tudo isto deve acrescentar-se o monopólio do trabalho e dos papéis de crédito, que se tornaram o quinhão de um pequeno número de ricos e de opulentos, que impõem assim um jugo quase servil à imensa multidão dos proletários" (RN, 3).

DSI e Marxismo se identificam em três ideias: 1 . O operário tem direito ao fruto do trabalho. A lei de oferta-demanda não pode ser o critério único para determinar o valor do salário. A dignidade do trabalho, a família e a necessidade do trabalhador são critérios fundamentais (RN, 31). O valor do salário deve ser determinado pelo acordo entre patrão e operário, corporações e sindicatos, com a mediação do Estado. 2. Intervenção do Estado na economia a fim de garantir as bases para a prosperidade da nação, o

${ }^{25}$ LEÃO XIII, Papa. Encíclica Rerum novarum (RN). Roma: Librería Editrice Vaticana, 1891. 
bem-estar dos operários, o respeito pela justiça, a administração pública e progresso da indústria, do comércio e da agricultura. É seu dever zelar por todos os cidadãos, mas com atenção especial ao operário responsável pela riqueza da nação (RN, 24). RN prescreve uma série de direitos trabalhistas: previdência, aposentadoria, emprego, seguro desemprego, seguro doença $(\mathrm{RN}, 40)$. 3. Universalização do direito de propriedade acompanhado pelas exigências do bem comum. $\mathrm{O}$ trabalho digno deve ser assegurado e a remuneração suficiente para constituir patrimônio (RN, 32-33).

A DSI se distancia de Marx no tocante à solução do conflito entre trabalho e capital (RN, 14): as duas classes não são inimigas, devem viver reconciliadas sob os auspícios da Igreja. Que cada classe cumpra com seus deveres. Os trabalhadores, com a fidelidade aos compromissos assumidos com o patrão. Os patrões devem respeitar a dignidade do operário, e não escravizá-lo: pagar um salário justo e evitar a fraude. A amizade entre as classes sociais funda-se no amor fraterno, todos são filhos do mesmo Pai.

A polêmica questão da luta de classes receberá novas intepretações no desenvolvimento da DSI. Logo na segunda encíclica social, a Quadragesimo anno (QA), Pio XII matizava: "a luta de classes, quando se abstém dos atos de violência e do ódio mútuo, transforma-se pouco a pouco em uma honesta discussão, fundada na busca da justiça. Se bem não é aquela bem-aventurada paz social, por que todos suspiramos, pode e deve ser o princípio da mútua colaboração" (QA, 114) ${ }^{26}$. João Paulo II, na encíclica Laborem exercens (LE) reconhece o papel positivo do conflito, quando ele se configura como luta pela justiça social (cf. LE, 11-15). No Compêndio, a DSI expõe os critérios éticos do direito de resistência: somente em última instância se admite o recurso à luta para se defender contra a injustiça, sobretudo se esta implica em violência. A resistência à opressão do poder político não recorrerá legitimamente às armas, salvo quando se ocorrerem conjuntamente as seguintes condições: 1 . Em caso de violações certas, graves e prolongadas dos direitos fundamentais; 2 . Depois de ter esgotado todos os outros recursos; 3 . Sem provocar desordens piores; 4. Que haja uma esperança fundada de êxito; 5 . Se for impossível prever razoavelmente soluções melhores. A luta armada é contemplada como extremo remédio para pôr fim a uma tirania evidente e prolongada que ofendesse gravemente os direitos fundamentais da pessoa humana e prejudicasse o bem comum do país ${ }^{27}$.

Quanto à questão da propriedade privada dos meios de produção, a DSI reconhece, como Marx, que no capitalismo, o conflito entre trabalho e

${ }^{26}$ PIO XI, Papa. Carta encíclica Quadragesimo Anno (QA), 213. Roma: Libreria Editrice Vaticana, 1931.

${ }^{27}$ PONTIFICIO CONSELHO JUSTIÇA E PAZ. Compendio da Doutrina Social da Igreja (CDSI). São Paulo: Paulinas, 2005, nn. 400-401. 
acesso à propriedade é um fato. "Com o trabalho permanece igualmente ligado, desde o princípio, o problema da propriedade" (LE, 12). Concorda com Marx, considerando que o direito de propriedade não é absoluto. Este princípio, consagrado na Gaudium et spes (GS), precede qualquer forma de propriedade. "Deus destinou a terra com tudo o que ela contém para o uso de todos os homens e povos; de modo que os bens criados devem chegar equitativamente às mãos de todos, segundo a justiça, secundada pela caridade" (GS, 67). Desse princípio geral decorre outro, a saber: "Aquele que se encontra em necessidade extrema tem o direito de procurar o necessário para si junto às riquezas dos outros" (GS, 69). É legítima a apropriação privada de bens, desde que esses bens cumpram sua função social. Os bens de produção, mesmo quando apropriados privadamente, devem servir ao bem comum e nunca podem ser usados contra as pessoas.

Em Laborem exercens (LE), a relação entre trabalho e propriedade se estabelece em função do seguinte princípio: "A propriedade se adquire antes de tudo mediante o trabalho e para que sirva ao trabalho" (LE, 14). Quanto à propriedade dos meios de produção, "servindo ao trabalho, tornem possível a realização do princípio anterior, que é o destino universal dos bens e o direito ao seu uso comum" (LE, 14). O magistério social nunca defendeu o direito de propriedade como intocável. Cabe ao Estado regular este direito.

\section{Centralidade do Trabalho}

\section{Marx: Trabalho, fator de humanização.}

O humanismo é uma nota distintiva em Marx. O fim do homem consiste no enobrecimento da sua humanidade. E o trabalho é a sua expressão maior. "A natureza produz o ser físico do homem; o trabalho engendra e desenvolve os atributos característicos pelos quais ele se eleva a uma ordem superior à da pura animalidade e se converte em portador de racionalidade e liberdade." ${ }^{28} \mathrm{O}$ homem se converteu no que é graças ao trabalho, condição natural da sua existência. Independente das modalidades é comum a todas as formas sociais por igual. Toda sociedade que almeja evoluir deve priorizar este motor do processo civilizatório e meio principal de desenvolvimento das potencialidades humanas. ${ }^{29} \mathrm{O}$ trabalho é um dos fundamentos da constituição da sociedade. As relações sociais têm origem no intercâmbio de produtos do trabalho, ou seja, quando aparece a vida econômica.

\footnotetext{
${ }^{28}$ Cf. La Ideología Alemana, p. 26-27.

${ }^{29}$ Cf. Manuscritos, p. 94.
} 
A centralidade do trabalho contém uma antropologia: o homem é produtor de si mesmo. As coisas, a vida, tudo é o resultado de processos humanos. "Toda a assim chamada história universal não é outra coisa que a geração do homem por meio do trabalho humano" ${ }^{30}$. Não há valor eterno nem verdade suprema. O humanismo, concretizado no comunismo, é a criação do homem pelo homem, único sentido da realidade e da história. O homem religioso somente é capaz de caminhar apoiado em deuses. É um ser dependente e sem autoconsciência. O mundo não é estático. É na relação dialética com o outro que o humanismo se processa. O humanismo integral é a criação do homem pelo homem. Enquanto o homem não for sua própria lei sempre haverá alienação religiosa. Somente a experiência da liberdade criadora pode eliminar o fantasma da religião. Se o homem é um ser plenamente reconciliado consigo mesmo, se encontra a sua essência em si mesmo, não pode haver lugar para a garantia dessa essência fora do homem. Nada existe fora dele ${ }^{31}$.

Esta antropologia está na raiz da crítica da religião presente em Marx. Não há lugar para Deus no processo de humanização. O próprio ateísmo perde sentido. O problema de Deus e o problema da criação estão superados. A crítica da religião chegou ao fim: Deus é produto do homem. A religião, por sua vez, é fruto da superstição e do medo. O único sujeito da história é o homem. É ele o agente de mudança.

A centralidade do trabalho justifica porque o único sujeito capaz de concretizar o humanismo pleno seja o proletariado. É ele o único ser social que sofre universalmente todas as mazelas da sociedade. Sua libertação significa a libertação da humanidade. A conjunção se dá entre teoria (filosofia) e práxis. Na situação do homem proletário e na revolução da classe do proletariado se encontra a única possibilidade de supressão de todas as desumanizações, a começar pela religiosa. A crítica da alienação religiosa pressupõe a crítica das alienações inferiores, até chegar à alienação econômica. A religião, como aliada do modo de produção capitalista, é uma religião alienante e perversa, uma ideologia. A supressão das alienações econômicas traz consigo a supressão da alienação religiosa. Marx se refere ao Cristianismo. A crítica da religião é um desafio lançado aos cristãos em primeiro lugar.

\section{DSI: Trabalho e personalismo}

Para a DSI o problema do capitalismo é antropológico. O processo de coisificação do trabalho o converteu em mercadoria e a pessoa humana passou a segundo plano. A primazia do capital sobre o trabalho resultou

${ }^{30}$ La Ideología alemana, p. 94.

${ }^{31}$ Cf.Manuscritos, p. 124- 125. 
na alienação da pessoa e da sociedade. Logo na sua origem, a DSI faz uma defesa da dignidade do operário contra a selvageria do capitalismo: "É vergonhoso e desumano usar dos homens como de vis instrumentos de lucro, e não os estimar senão na proporção do vigor dos seus braços" $(R N, 10)$.

João Paulo II, em Laborem exercens ${ }^{32}$, foi quem elaborou a crítica mais sólida contra a desumanização do trabalho. Ao identificar o nexo entre os materialismos históricos - o capitalismo liberal foi a premissa da filosofia marxista - o capitalismo realizou esta inversão. O capital transformou o trabalho em instrumento de acumulação material (LE, 13). A única forma de superar essa inversão é introduzir mudanças tanto no campo teórico como na prática na linha do primado da pessoa sobre as coisas, do trabalho sobre o capital.

Na perspectiva personalista, a centralidade da dignidade humana é a razão para pensar sobre o trabalho. "O homem é o autor, o centro e o fim da vida econômico social" (GS, 63) ${ }^{33}$. A lei fundamental do desenvolvimento econômico "não é o mero incremento da produção, aumentando a vantagem, ou poder, mas o serviço do homem integral" (GS, 64). Portanto, o trabalho - como a atividade humana por excelência - "é muito superior aos outros elementos da economia, uma vez que estes não têm outra função que de instrumentos" (GS, 67) ${ }^{34}$. O conceito de pessoa, núcleo da antropologia personalista, é o fundamento de toda práxis. O trabalho não está pensado a partir dos sistemas econômicos. O trabalho, que "ocupa o centro da questão social" (LE, 2), é um dos contextos mais ricos para captar a complexidade dos condicionamentos e inter-relações que perpassam a existência humana.

A partir deste pressuposto, a DSI compreende o sentido do trabalho à luz da revelação ${ }^{35}$. A salvação que é oferecida em Cristo se realiza na vida nova

\footnotetext{
32 JOAO PAULO II, Papa. Encíclica laborem exercens (LE). Sobre o exercício do trabalho. Roma: Libreria Editrice Vaticana, 1981.

${ }^{33}$ CONCÍLIO VATCANO II. Constituição Pastoral Gaudium et spes (GS). Sobre a Igreja no mundo contemporâneo. Roma: Libreria Editrice Vaticana, 1965.

${ }^{34} \mathrm{O}$ trabalho "procede imediatamente da pessoa, a qual como que marca com o seu zelo as coisas da natureza, e as sujeita ao seu domínio. É com o seu trabalho que o homem sustenta de ordinário a própria vida e a dos seus; por meio dele se une e serve aos seus irmãos, pode exercitar uma caridade autêntica e colaborar no acabamento da criação divina" (GS, 67). Continua o texto: "Daí nasce para cada um o dever de trabalhar fielmente, e também o direito ao trabalho; à sociedade cabe, por sua parte, ajudar em quanto possa, segundo as circunstâncias vigentes, os cidadãos para que possam encontrar oportunidade de trabalho suficiente. Finalmente, tendo em conta as funções e produtividade de cada um, bem como a situação da empresa e o bem comum, o trabalho deve ser remunerado de maneira a dar ao homem a possibilidade de cultivar dignamente a própria vida material, social, cultural e espiritual e a dos seus." O parágrafo seguinte oferece critérios para uma organização da economia que respeite os trabalhadores.

${ }^{35}$ Cf. Gaudium et spes. Capítulo III da Parte I nn. 33-39.
} 
na plenitude do Reino que abrange a história e as realidades humanas. A DSI funda na revelação a ideia de que "o sujeito do trabalho é sempre a pessoa humana imagem de Deus, capaz de autodeterminação e que busca sua realização" (LE, 6). O valor do trabalho está vinculado ao seu executor. "Oferecendo a Deus o seu trabalho, o homem se associa à obra redentora de Cristo, o qual conferiu ao trabalho uma dignidade sublime, trabalhando com as suas próprias mãos em Nazaré" (GS, 67). A atividade humana individual e coletiva, aquele imenso esforço com que os homens, no decurso dos séculos, tentaram melhorar as condições de vida, corresponde à vontade de Deus (GS, 34). Este aspecto revela a dimensão escatológica do trabalho como uma projeção da dimensão transcendente da pessoa.

João Paulo II distingue no trabalho duas dimensões. Em sentido objetivo é o conjunto de atividades, recursos, instrumentos, técnicas, formas de gestão e tecnologias $(L E, 5)$. Em sentido subjetivo é o agir humano enquanto leva a cabo as ações que pertencem ao processo do trabalho e correspondem à sua vocação de ser imagem e semelhança de Deus, chamadas a prolongar ajudando-se mutuamente, na obra da Criação (LE, 6). É a afirmação do primado da pessoa sobre a organização do trabalho e sobre os bens produzidos. Seu caráter perene está confirmado pelo conteúdo nuclear do cristianismo: "Aquele que, sendo Deus, se tornou semelhante a nós em tudo, passou a maior parte da sua vida sobre a terra junto de um banco de carpinteiro, dedicando-se ao trabalho manual" (LE, 6).

A humanização depende da prioridade do trabalho sobre o capital (LE, 12). Trata-se da "tradução, em termos econômicos, do princípio ético do primado das pessoas sobre as coisas". Portanto, o trabalho é um meio imprescindível de humanização: "Quando o homem, usando as suas mãos ou recorrendo à técnica, trabalha a terra para que ela produza frutos e se torne habitação digna para toda a humanidade ... ao mesmo tempo se vai aperfeiçoando a si mesmo" (GS, 57).

\section{Diferenças}

\section{Identidade}

Marxismo: teoria crítica da economia política e instrumental de análise.

O marxismo não é apenas uma teoria que fundamenta o socialismo e o comunismo. O marxismo é uma teoria crítica da sociedade capitalista. É um sistema científico a serviço do proletariado em sua luta contra a burguesia e a ideologia da classe dominante. Como teoria crítica abrangente 
da história e da natureza, constitui um saber aberto: é científico, sociológico e filosófico. É, também, uma reinterpretação do idealismo dialético de Hegel, a filosofia clássica alemã e o socialismo francês. Apresenta-se como uma visão da vida, de mundo e da história do ponto de vista das classes exploradas pelos donos do capital.

Em primeiro lugar, Marx construiu sua obra como uma crítica da economia política sustentada na tese do materialismo histórico. Sua crítica da economia política, fiel à sua concepção de história, não compreende apenas uma interpretação das representações falsas. Ela é, ao mesmo tempo, uma crítica das condições materiais, sociais que produzem essas falsas representações (ideologia da economia política burguesa).

Em segundo lugar, o marxismo é um sistema filosófico do qual emanam o socialismo e o comunismo como possibilidades de modelos de sociedade. Estas intuições não contradizem sua natureza cientifica. Sua interpretação da história conduz necessariamente, e de forma coerente, à transformação da sociedade. Neste sentido, é uma filosofia da práxis que tem, entre seus objetivos, despertar movimentos de emancipação do proletariado através de revoluções que gerem sociedades sem classes sociais.

O viés revolucionário desta filosofia encontra sua justificação no fato real de que o Estado burguês não abdica dos mecanismos violentos para controlar e reprimir seus opositores. A sociedade capitalista é regida pelas suas próprias contradições geradoras de constantes crises sociais. Após uma série de crises cíclicas, chegaria, enfim, a crise das crises. Nesse momento se dariam as condições para a revolução dos trabalhadores. Mas somente neste momento, nunca antes... O Partido "não quer chocar-se contra um muro e lançar-se a uma sangrenta revolução de um contra $\mathrm{dez}^{\prime \prime 36}$. A luta de classes é o motor da história. A velha sociedade grávida de uma nova se vê diante de uma diferente parteira: a classe operária. A boa notícia aos oprimidos é esta: “quem será expropriado, agora, não é mais o trabalhador que trabalha para si próprio, mas o capitalista que explora muitos trabalhadores" ${ }^{37}$.

Por último, a respeito dos modelos de sociedade, a diferença básica entre o socialismo e o comunismo é que o primeiro é uma fase de transição necessária pela qual a sociedade passará para chegar ao segundo. No socialismo, a sociedade controlaria a produção e distribuição dos bens em um sistema que prezasse a igualdade e a cooperação. Nesta transição, o Estado ajudaria a solidificar o novo sistema em vista da sua evolução para atingir o comunismo. Neste, as propriedades privadas dos meios de

\footnotetext{
${ }^{36}$ Carta de Marx e Engels a Bebel (1879). In: MARX, Karl, y ENGELS, Friedrich. Correspondência. Cartago: Buenos Aires, 1973, p. 303.

${ }^{37}$ MARX, Karl. O Capital, livro I, São Paulo: Boitempo, 2013, p. 832.
} 
produção deixariam de existir, também as classes sociais e o Estado tal como concebidos no capitalismo. Os trabalhadores seriam os proprietários de seu trabalho e dos meios de produção. Constituir um modelo de sociedade radicalmente oposto ao capitalismo, essa é a esperança de Marx.

\section{DSI: Teologia Moral Católica}

A identidade primeira da DSI é pertencer ao campo da teologia moral. É herdeira da tradição cristã iniciada na Sagrada Escritura que alcança seu ponto mais alto em Jesus, continua na patrística e na escolástica e chega aos teólogos e ao magistério contemporâneo. A DSI "está construída sobre o fundamento que foi transmitido pelos Apóstolos aos Padres da Igreja e, depois, acolhido e aprofundado pelos grandes Doutores cristãos. Tal doutrina remonta, em última análise, ao Homem novo, ao último Adão que se tornou espírito vivificante $(1$ Cor 15,45$)$. É princípio da caridade que nunca acabará (1 Cor 13,8). Nela se exprime a missão profética que têm os Pontífices de guiar apostolicamente a Igreja de Cristo e discernir as novas exigências da evangelização" $(\mathrm{CV}, 12)^{38}$.

A Doutrina Social é da Igreja, pertence à comunidade eclesial e está vinculada às suas fontes (DV 10). Sua melhor definição pode ser encontrada em João Paulo II. A DSI "é um corpo doutrinal atualizado, que se articula à medida que a Igreja, dispondo da plenitude da palavra de Deus revelada por Cristo Jesus e com assistência do Espírito Santo, vai lendo os acontecimentos, enquanto eles se desenrolam no decurso da história" (SRS, 1) ${ }^{39}$. Seu discurso inspira-se no Evento Cristo. "Nele, a história recebeu uma perspectiva escatológica com implicações ético-sociais. O amor de Deus está voltado para o ser humano. Teologia, sociedade e ética são faces de uma única moeda. A dimensão social é inseparável da experiência de Deus"40.

Em segundo lugar, a DSI concretiza o empenho da Igreja de propor um humanismo à altura do Evangelho. Ao expressar a imagem de um Deus presente na história humana, comprova que o Cristianismo é, essencialmente, uma religião ética. "A ética leva a Deus que espera uma resposta comprometida que está fora das categorias do mercado" (EG, 54).

Em terceiro lugar, a DSI se caracteriza como uma teologia pública que inspira modelos de organização social baseados na justiça, na dignidade

\footnotetext{
${ }^{38}$ BENTO XVI, Papa. Encíclica Caritas in Veritate (CV). Sobre o desenvolvimento humano integral na caridade e na verdade. Roma: Libreria Editrice Vaticana, 2009.

${ }^{39}$ JOAO PAULO II, Papa. Encíclica Sollicitudo rei socialis (SRS). Roma: Libreria Editrice Vaticana,1987.

${ }^{40}$ GASDA, Élio. Dimensão ético-social: memória subversiva de um Deus Crucificado: Rev. Pistis Praxis Teologia EPastoral (Curitiba), v. 10, n. 2, 269-289, 2018, p. 272.
} 
humana e no bem comum ${ }^{41}$. Ela não se restringe aos parâmetros políticos ou socioeconômicos. Não se confunde com projeto programático de modelo de sociedade. Também não se limita a um método de análise social. $\mathrm{O}$ que se propõe é interpretar as realidades sociais à luz do Reino de Deus e da tradição teológica, a fim de oferecer elementos éticos para a práxis cristã na vida pública.

A DSI é uma tradução elaborada das consequências da esperança cristã na sociedade e na política. Esta esperança escatológica tem seu fundamento em Cristo crucificado-ressuscitado. Por isso ultrapassa o horizonte da história humana e não se esgota em modelos de sociedade. Projeto humano algum consegue concretizar todo o conteúdo da esperança cristã presente no conceito Reino de Deus. Mas a esperança em um novo céu e uma nova terra mantém os cristãos imbuídos da liberdade cristã. O Reino inaugurado por Ele carrega a dimensão da esperança: em sua vida, morte e ressurreição o Reino já se faz presente, mas está aberto a sua consumação futura. O Reino já começou, mas ainda não se consumou. Esperar o Reino significa ser conduzido por seus valores e exigências. Este futuro prometido é antecipado pela experiência de fé no Crucificado-Ressuscitado, personificação das coisas últimas que dá sentido à história $(1$ Cor 15,17).

O Reino de Deus é o núcleo central da esperança que sustenta o pensamento da DSI: "O Senhor derrubou os poderosos de seus tronos e exaltou os humilhados. Encheu de bens os famintos, e mandou embora os ricos de mãos vazias" (Lc 1, 52-53). Sua consumação é o objeto de todos os que esperam novos céus e nova terra (2Ped 3,13). O compromisso político é "uma forma de dar culto a Deus" (Puebla, 521). "A Igreja que, em razão da sua missão e competência, de modo algum se confunde e nem está ligada a qualquer sistema político determinado" (GS,76). O lugar dos cristãos na política implica participar na construção de uma nova sociedade a partir do compromisso com os pobres. A DSI quer "contribuir para que as exigências da justiça se tornem compreensíveis e politicamente realizáveis" (Deus caritas est, 28$)^{42}$. No tocante à esperança no Reino de Deus, os modelos de sociedade e os projetos políticos sempre serão relativos, nunca absolutizados.

Em suma: o objetivo, para o marxismo, é alcançar a sociedade comunista sem classes. O sujeito construtor da nova sociedade é classe do proletariado, os trabalhadores pobres. O objetivo da DSI é ajudar os cristãos a viver e testemunhar a esperança no Reino de Deus, antecipando sua realidade em sinais concretos. $\mathrm{O}$ sujeito dos processos de libertação são todos os pobres e seus aliados. Pobre entendido não somente como classe social

${ }^{41}$ GASDA, Élio. Política, Cristianismo e laicidade: Perspectiva Teológica (Belo Horizonte), v. 47, n. 132, 2015, p. 203-220.

${ }^{42}$ BENTO XVI, Papa. Encíclica Deus caritas est (DCE). Roma: Libreria Editrice Vaticana, 2005. 
econômico. Trata-se de um conceito mais amplo que o proletariado. Pobre não é apenas alguém privado economicamente, mas também o negro, o indígena, a mulher, a comunidade LGBT, o migrante, o idoso, a população em situação de rua. Não só. Pobre é, também, uma categoria teológica: todo injustiçado, empobrecido e humilhado é sacramento da presença de Deus. E um conceito carregado de significações morais, bíblicas, religiosas. Deus é definido como o Deus dos pobres. A opressão sobre os pobres são pecados contra Deus.

\section{Do confronto ao diálogo}

\section{Intolerância e incompreensão mútua}

DSI, por sua natureza teológica-moral, é independente e crítica de todas as teorias e modelos de sociedade que prescindem de Deus. O enfrentamento da Igreja com os dois modelos de sociedade - Capitalismo Liberal e Socialismo Marxista - caracteriza todo o período da DSI que compreende a encíclica Rerum novarum (1891) até o Concílio Vaticano II (1962-1965).

A guerra entre comunismo e cristianismo havia fixado a relação entre ambos: o anátema de uma parte correspondia a liquidação de outra. Teria razão Marx? Cristianismo é alienante ou emancipador? Teriam razão os cristãos? O marxismo promove a violência entre as classes sociais e é inimigo da religião? A DSI tem um posicionamento crítico diante do marxismo desde suas origens. Em 1937, Pio XI na encíclica Divini Redemptoris (DR) - sobre o comunismo ateu ${ }^{43}$ - expressava seu temor diante do perigo ameaçador do "comunismo, denominado bolchevista e ateu, que se propõe como fim peculiar revolucionar radicalmente a ordem social e subverter os próprios fundamentos da civilização cristã" (DR, 3). Tal comunismo se funda nos princípios do materialismo chamado dialético e histórico ensinado por Karl Marx. Quando há apenas uma realidade universal, a matéria e o homem, não há lugar para a ideia de Deus (DR, 7).

João XXIII, em Pacem in terrris (PT), marca uma nova postura da Doutrina Social da Igreja diante da nova configuração do socialismo. O documento introduz a distinção entre ideologia e movimentos históricos: "Cumpre não identificar falsas ideias filosóficas sobre a natureza, a origem e o fim do universo e do homem com movimentos históricos de finalidade eco-

${ }^{43}$ PIO IX, Papa. Enciclica Divini Redemptoris - Sobre o comunismo ateu. Roma: Libreria Editrice Vaticana, 1937. 
nômica, social, cultural ou política, embora tais movimentos encontrem nessas ideias filosóficas a sua origem e inspiração. A doutrina, uma vez formulada, é aquilo que é, mas um movimento, mergulhado como está em situações históricas em contínuo devir, não pode deixar de lhes sofrer o influxo e, portanto, é suscetível de alterações profundas. De resto, quem ousará negar que nesses movimentos, na medida em que concordam com as normas da reta razão e interpretam as justas aspirações humanas, não possa haver elementos positivos dignos de aprovação?" (PT, 158).

A lenta mudança na compreensão da relação da Igreja com a sociedade chegou ao Concílio Vaticano II e levou ao aggiornamento da DSI. O Concílio quer se dirigir a todos, "à luz do Evangelho e da experiência humana" (GS, 46). Essa postura permitiu o descongelamento da relação e deu a palavra aos estudiosos mais críticos com interpretações mais imparciais. Começou-se a tomar consciência da complexidade de um problema que havia sido simplificado. Por um lado, a obra de Karl Marx ajuda a entender as teorias da acumulação capitalista e os muitos problemas sociais gerados pela economia política de mercado. Por outro, a DSI defende que a economia e política precisam ser redesenhadas segundo normas morais e princípios éticos que garantam a dignidade humana e a justiça.

Paulo VI começa sua abordagem em Octogesima adveniens $(\mathrm{OA})^{44}$ sobre o socialismo partindo do parágrafo supracitado de Pacem in terris. A partir dele, analisa a atração do pensamento marxista sobre os católicos. "Há cristãos que se sentem atraídos pelas correntes socialistas e pelas suas diversas evoluções. Eles procuram descobrir aí certo número de aspirações, que acalentam em si mesmos, em nome da sua fé (OA, 31); outros cristãos se perguntam, se uma evolução histórica do marxismo não permitiria algumas aproximações concretas (OA, 32). Em outra perspectiva, o marxismo apresenta-se como uma atividade científica, como um método rigoroso de exame da realidade social e política (n. 33). De fato, muitos intelectuais cristãos utilizam a análise marxista distinguindo-a da filosofia e da práxis marxista. A atenção às ideologias, aos fatores econômicos, às estruturas sociais que orientam a sociedade, a exploração dos pobres e suas lutas. O materialismo histórico carrega consigo uma crítica da religião de grande importância em sociedades em que a religião é utilizada para justificar injustiças e desigualdades. Frente a esta aproximação ao marxismo, segundo Paulo VI, "um discernimento cuidadoso é necessário" (OA, 31).

Vinte anos depois, João Paulo II ${ }^{45}$ reitera que nenhum sistema socioeconômico e político pode ser o horizonte de sentido definitivo da história. Qualquer ideologia puramente materialista do desenvolvimento humano

${ }^{44}$ PAULO VI, Papa. Carta apostólica Octogesima adveniens (OA). Roma: Libreria Editrice Vaticana, 1971.

${ }^{45}$ JOÃO PAULO II, Papa. Encíclica Centesimus annus (CA). Roma: Libreria Editrice Vaticana, 1991. 
é contrária à verdade integral da pessoa humana e ao projeto de Deus (CA, 41). O juízo não se aplica somente ao marxismo. A análise marxista implica de fato em um conceito da história que não concorda com a visão cristã de pessoa e de sociedade. É perigoso aceitar os elementos da análise marxista sem reconhecer suas relações com a ideologia. A DSI faz um apelo aos cristãos para que estudem mais profundamente o problema das estruturas sociais.

\section{Três ilustrações da aproximação}

A porta ao diálogo aberta pelo Concílio Vaticano II foi bem acolhida por alguns marxistas, como Roger Garaudy: “O futuro do homem não poderá ser construído nem contra os crentes, nem tampouco sem eles; o futuro do homem não poderá ser construído nem contra os comunistas, nem mesmo sem eles" ${ }^{\prime 6}$. Garaudy faz eco de um texto de Friedrich Engels onde afirmou que entre o cristianismo primitivo e o movimento operário tinham em comum que ambos pregavam a libertação, mas "o cristianismo transpõe essa libertação para o além, numa vida depois da morte, no céu" ${ }^{47}$.

Padre Pedro Arrupe, Superior Geral da Companhia de Jesus entre 1965 e 1983, aconselhou seus companheiros a manterem-se sempre dispostos ao diálogo, no que concerne aos marxistas ${ }^{48}$. O teólogo francês Jean-Yves Calvez publicou $O$ pensamento de Karl Marx ${ }^{49}$, no qual promoveu uma aproximação teórica com o pensamento de Marx, despertando os católicos para um maior conhecimento do marxismo. A leitura de Marx via Yves Calvez, era uma busca de conciliação com Marx ${ }^{50}$. Paul Lehmann, no texto intitulado Ética cristã - Ética marxista, enumerava as semelhanças entre a filosofia cristã e a marxista. A convicção de que a libertação do homem se realizará messianicamente é uma esperança comum ao cristianismo e ao marxismo. No cristianismo, esta missão será exercida através da comunidade cristã. No marxismo, será pelo proletariado ${ }^{51}$.

A primeira ilustração pode ser facilmente encontrada na América Latina. A Teologia da Libertação (TdL) surgida no contexto do Vaticano II, tinha como um dos objetivos, despertar nos pobres a consciência de seu protagonismo como sujeitos históricos de sua própria emancipação. O primeiro passo

\footnotetext{
${ }^{46}$ GARAUDY, Roger. Do Anátema ao diálogo. Rio de Janeiro: Paz e Terra, 1966, p. 10.

${ }^{47}$ ENGELS, Friedrich. Contribuição para a história do cristianismo primitivo (1895). Rio de Janeiro: Laemmert, 1972, p. 353.

${ }^{48}$ Cf. ARRUPE, Pedro. "Análise marxista." Coleção Ignatiana, n. 17,1981, p. 5-13.

${ }^{49}$ CALVEZ, Jean-Yves. El pensamiento de Carlos Marx, Madrid, Taurus, 1966.

${ }^{50}$ PALÁCIO, Carlos (org.). Cristianismo e história. São Paulo: Loyola, 1982, p. 19.

${ }^{51}$ Cf. LEHMANN, Paul. Ética cristã, ética marxista: Revista Paz e Terra, n. 1: Rio de Janeiro: Paz e terra, julho, 1966 p. 156-157.
} 
no processo metodológico da TdL é o ver. Daí a necessidade do recurso à mediação sócio-analítica, que fornece o conhecimento da realidade social. Como assinala Clodovis Boff, "o texto da leitura teológica a propósito do político lhe é preparado e oferecido pelas ciências do social. A teologia o recebe delas e sobre ele pratica uma leitura correspondente ao seu código próprio, de modo a tirar daí o sentido caracterizadamente teológico" ${ }^{252}$.

É nesta condição de matéria prima que sua corrente majoritária serviu-se do instrumental marxista ${ }^{53}$. Mostrou-se válido enquanto método de análise da realidade por algumas correntes desta teologia. ${ }^{54}$ Seu ponto de partida foi a realidade brutal da pobreza e da violência. Se a realidade social é fruto de decisões humanas e históricas, ela pode ser modificada. O projeto de uma sociedade fraterna, justa e igualitária é muito próximo do projeto do Reino de Deus inaugurado e anunciado por Jesus Cristo. O ponto de chegada é a libertação do homem, no sentido do humanismo cristão que, transcendental, ao contrário do humanismo marxista e existencialista, assume e finaliza o desenvolvimento do homem todo e de todos os homens a divinização em Cristo.

A TdL se baseia na Revelação, não nas ciências humanas, uma vez que estas são usadas apenas em uma etapa anterior para analisar a realidade. A TdL utiliza algumas categorias da teoria de Marx que explicam o funcionamento do capitalismo. O conceito de Luta de Classes, por exemplo, é utilizado para compreender as disputas de terra, os movimentos sociais reivindicatórios, o uso da violência contra os mais pobres, a exploração do trabalhador e as diversas formas de exclusão social. É um instrumento, não um fundamento. Entre os movimentos sociais, o chileno "Cristãos para o Socialismo" viveu um processo mais claro de síntese entre cristianismo e marxismo. Era uma corrente cristã no seio do movimento revolucionário.

A segunda ilustração vem da Europa. A Guerra Fria entrou em declínio em 1991 com a desintegração da União Soviética. Muitos partidos e grupos socialistas ou comunistas tornaram-se socialdemocratas. A análise marxista não representa mais uma ameaça à fé cristã. Até um arcebispo católico, de Munique, Reinhard Marx lançou, em 2011, um livro intitulado $O$ Capital - um legado a favor da humanidade. A capa contém as mesmas cores e fontes gráficas da primeira edição de $O$ Capital, de Karl Marx, publicada em Hamburgo em 1867. Na Europa, os contatos com a rede de marxistas tiveram início em 2014 entre o Papa Francisco, Aléxis Tsípras e Walter Baier. Tsípras era vice-presidente do Partido

\footnotetext{
${ }^{52}$ BOFF, Clodovis. Teologia e prática. Teologia do político e suas mediações. Petrópolis: Vozes, 1978, p. 84.

${ }^{53}$ BORDIN, Luigi. O Marxismo e a Teologia da Libertação. Rio de Janeiro: Dois Pontos, 1987.

${ }^{54}$ Ibidem, p. 119.
} 
da Esquerda Europeia, do partido de esquerda Synaspismós (SYN) e líder da Coligação da Esquerda Radical (Syriza). Baier é o coordenador da rede europeia de organizações marxistas Transform presente em 18 países. Entre 1994 e 2006 foi presidente do Partido Comunista da Áustria. É ligado ao movimento católico Focolares. O primeiro "encontro de trabalho" entre o Vaticano e os marxistas europeus aconteceu entre 31 de março e 1 de abril de 2016, no Instituto Universitário Sophia (fundado por Chiara Lubich). Cada um dos participantes tem suas próprias convicções filosóficas e/ou teológicas - que não são as mesmas, nem entre os marxistas e nem entre os católicos. Estas convicções gozam de respeito mútuo, mas não são objeto da discussão. $\mathrm{O}$ diálogo trata de problemas sociais, políticos e éticos atuais - os ataques aos migrantes, a crise ecológica, o neoliberalismo e a injustiça social - e de possíveis alternativas. Há um denominador comum que une cristianismo e marxismo: os direitos dos pobres e seus anseios de libertação.

A cultura do encontro, proposta por Papa Francisco, é a terceira e a mais importante ilustração da aproximação entre DSI e Marx. O conceito de ecologia integral possibilita um diálogo capaz de alcançar consensos e "acordos para viver juntos (...) um pacto social e cultural" (EG, 239). Em Laudato si (LS), Francisco propõe empreender em todos os níveis da vida social, econômica e política um diálogo honesto que inaugure processos alternativos. "Um debate científico e social que seja responsável e amplo, capaz de considerar toda a informação disponível e chamar as coisas pelo seu nome a partir de linhas de pesquisa autónomas e interdisciplinares que possam trazer nova luz" (LS, 135). O Papa apela ao "diálogo social como contribuição para a paz" (LS, 63). O diálogo supõe uma visão plural e envolve todos os atores envolvidos, todas as disciplinas intelectuais. A Igreja não possui o monopólio da interpretação da realidade social (EG, 184). A DSI não oferece soluções técnicas, "ela não pretende definir as questões científicas nem substituir a política, mas convidar a um debate honesto e transparente, para que as necessidades particulares ou as ideologias não lesem o bem comum" (LS, 188).

O primeiro aspecto é a crítica do capitalismo, um sistema classificado como terrorista ${ }^{55}$. Esta economia é insuportável: "Para além de qualquer previsão catastrófica, o certo é que o atual sistema mundial é insustentável por diversos pontos de vista" (LS, 139). Este pontífice conhece de perto os desastres da idolatria do dinheiro geradora de uma escandalosa acumulação de riqueza em pouquíssimas mãos à custa da exclusão e da pobreza das grandes maiorias. ${ }^{56}$ "Este sistema social e econômico é injusto em sua raiz" (EG, 59).

${ }^{55}$ III Encontro.

${ }^{56}$ GASDA, Élio. Essa economia mata (EG, 53). Crítica teológica do capitalismo inviável: Rev. Perspectiva Teológica, vol. 49, n. 3, 2017, p. 573-578. 
O Documento Oeconomicae et pecuniariae quaestiones ${ }^{57}$, acusa de forma contundente o sistema atual, condena seu males e lamenta a impotência do poder político diante do poder financeiro. O texto denuncia a irresponsabilidade "sem rosto" do mercado e seu acelerado distanciamento do bem comum, dos direitos humanos e trabalhistas e da democracia. O sistema opera em um vazio ético. Seu único imperativo é a maximização dos lucros buscados "a qualquer custo". Não se deve sacrificar a vida e a dignidade das pessoas a nenhum poder.

"Essa economia mata" (EG, 53). Francisco atinge o coração ideológico do sistema: "Não podemos confiar nas forças cegas e na mão invisível do mercado" (EG, 204). Serve-se de categorias marxistas: "mecanismos sacralizados" (EG, 54), fetichismo do dinheiro (EG, 55), ideologia da autonomia absoluta dos mercados (EG, 56) ${ }^{58}$.

Trabalhador reduzido a mercadoria submetido às leis do mercado (EG, 53). Outro aspecto da aproximação é a grande preocupação de Francisco com os trabalhadores. A exploração do trabalho é uma das causas principais da desigualdade e da exclusão social. "Não existe pior pobreza material - urge enfatizar isto - não existe pior pobreza material do que a que não permite ganhar o pão e priva da dignidade do trabalho" 59 . Os direitos trabalhistas nasceram das lutas do proletariado e encontram apoio na DSI: "O amor pelos pobres está no centro do Evangelho. Terra, teto e trabalho - isso pelo qual vocês lutam - são direitos sagrados. Reivindicar isso é doutrina social da Igreja" ${ }^{\prime 60}$. Seus encontros com os trabalhadores são constantes. O mundo do trabalho é parte da solução da crise socioambiental.

O terceiro e último aspecto é busca de alternativas ao sistema. A única solução é mudança de estruturas ${ }^{61}$. "Precisamos converter o modelo de desenvolvimento global, e isto implica refletir sobre o sentido da economia

\footnotetext{
${ }^{57}$ CONGREGAÇÃO PARA A DOUTRINA DA FÉ; DICASTÉRIO PARA O SERVIÇO DO DESENVOLVIMENTO HUMANO INTEGRAL. Oeconomicae et pecuniariae quaestiones: considerações para um discernimento ético sobre alguns aspectos do atual sistema econômico-financeiro, 2018.

${ }^{58}$ A expressão "ditadura da economia ou do dinheiro" não é nova na DSI. Ela aparece na encíclica de Pio XI em 1931, Quadragesimo Anno: “a livre concorrência matou-se a si própria; a ditadura da economia se impôs sobre a liberdade de mercado; a avidez do lucro foi seguida pela desenfreada ambição de poder; toda a economia se tornou horrendamente dura, cruel, atroz" (109).

${ }^{59}$ FRANCISCO, Papa. I Encontro Mundial de Movimentos Populares. Disponível em: $<$.https://w2.vatican.va/content/francesco/pt/speeches/2014/october/documents/papa-francesco_20141028_incontro-mondiale-movimenti-populari.html $>$.Aceso em: 15/04/2019. Em continuação: I Encontro

${ }^{60}$ I Encontro.

${ }^{61}$ FRANCISCO, Papa. II Encontro Mundial de Movimentos Populares.Disponível em: <https:// w2.vatican.va/content/francesco/pt/speeches/2015/july/documents/papa-francesco_20150709_ bolivia-incontro-mondiale-movimenti-populari.html >. Aceso em: 15/04/2019. Em continuação: II Encontro.
} 
e dos seus objetivos, para corrigir as suas disfunções. Trata-se de redefinir o progresso" (LS, 194). O diálogo com todas as forças sociais e políticas deve buscar novos modelos socioeconômicos (LS, 94) e propor sistemas normativos que incluam limites à economia e assegurem a proteção dos ecossistemas (LS, 53).

Os semeadores de mudança estão nas periferias do mundo ${ }^{62}$. O protagonismo é atribuído aos movimentos populares organizados em torno do trabalho. "O futuro da humanidade não está somente nas mãos dos grandes líderes, das grandes potências e das elites. Está, sobretudo, nas mãos dos povos; na sua capacidade de organizar-se e também nas mãos que irrigam, com humildade e convicção, este processo de mudanças. Os povos do mundo querem ser artífices do seu próprio destino. Nenhum poder efetivamente constituído tem direito de privar os países pobres do pleno exercício da sua soberania ${ }^{63}$. "Os pobres não só padecem a injustiça, mas também lutam contra ela! Basta de passividade a espera de soluções que venham de cima." ${ }^{\prime 64}$

A primeira tarefa é pôr a economia a serviço dos povos. A economia não deveria ser um mecanismo de acumulação, mas administração da casa comum. A justa distribuição dos frutos da terra e do trabalho humano não é filantropia. É dever moral. ${ }^{65}$ Passar de uma economia que visa somente o lucro, baseada em especulação e nas finanças, para uma economia social que investe em pessoas e garanta o acesso aos "três T": Terra, Teto, Trabalho. O sistema econômico deve ser controlado pela comunidade política e pela ética (LS, 189-198). Esta perspectiva implica priorizar as necessidades dos últimos sobre os interesses dos ricos. Trata-se de uma alteração radical da ordem vigente. "O futuro da humanidade está, em grande medida na vossa capacidade de vos organizar e promover alternativas criativas na busca diária dos "3 $\mathrm{T}$ " e na participação como protagonistas nos grandes processos de mudança nacionais, regionais e mundiais" ${ }^{\prime 6}$.

\section{Considerações finais}

A DSI não é um instrumento da Igreja para combater o comunismo. Marx não criou uma teoria para combater a Igreja. Ambos carregam preocupações mais nobres.

\footnotetext{
${ }^{62}$. Cf. II Encontro.

${ }^{63}$ Cf. II Encontro

${ }^{64} \mathrm{Cf}$. I Encontro

${ }^{65}$ Cf. III Encontro.

${ }^{66}$ II Encontro.
} 
A DSI não é marxista. E o marxismo não é doutrina social. Assim como Marx não inventou o socialismo, a DSI não inventou a dimensão social do cristianismo. Papa Francisco é discípulo de Jesus. Justiça social, opção pelos pobres, defesa dos direitos dos trabalhadores são temas recorrentes na DSI bem antes de Marx e de Rerum novarum. Não são invenção do marxismo nem da DSI. Não faltaram homens e mulheres de fé que se levantaram em defesa dos pobres. Profetas do Antigo Testamento já denunciavam a estrutura da sociedade oligárquica de Israel. As duras palavras de São Basílio, São João Crisóstomo, Francisco de Vitória, Bartolomeu de Las Casas contra os opressores e em defesa dos pobres ainda ecoam. Porém, em parte, Marx tinha razão: parte das religiões tornou-se "ópio do povo" e útil ao capital. Também a Igreja contribuiu para dar um caráter sagrado à ordem vigente. Mas as religiões têm uma riqueza a oferecer para o processo de humanização do indivíduo e da sociedade.

O pensamento de Karl Marx e a DSI, cada um a seu modo, podem ser enquadrados na tradição do humanismo desenvolvido no Ocidente. Ambos têm em comum a preocupação pelas categorias sociais empobrecidas, exploradas ou excluídas das sociedades. Com a Revolução Industrial, a realidade dos pobres e o mundo do trabalho estão interconectados.

O Marxismo é uma ciência das relações sociais, da história e do homem. Em Marx, a humanidade do proletário é o eixo central. Em torno dele orbitam os demais temas: crítica da religião, crítica da economia política do capitalismo, propriedade privada. A alienação gerada e sustentada pelo capitalismo está na raiz de todas as opressões. A revolução chega a seu termo final somente após a constituição de um modelo de sociedade específico: comunismo, do qual o socialismo é uma etapa de transição. A revolução começa no próprio homem e se expressa na transformação das estruturas.

A DSI é uma teologia moral que brota da ética do Reino de Deus. Seu ponto de partida é a iniciativa divina. Todos os temas sociais são tratados neste horizonte. O pecado, ruptura de amizade com Deus e com o próximo, está na origem de todas as opressões históricas. A libertação da escravidão do pecado exige a libertação das escravidões históricas de ordem cultural, socioeconômica e política que impedem a plena humanização. Desta convicção de fé nasce o compromisso de transformar as estruturas injustas para restabelecer o respeito pela dignidade humana. As autênticas lutas de libertação social são sinais incompletos, no tempo, da libertação oferecida em Cristo. Todos são chamados a essa humanidade nova. Somente homens novos podem construir uma nova sociedade.

A DSI tem se apresentado como um canal privilegiado do diálogo honesto da Igreja com os marxistas. Deve-se rejeitar as tentativas de se aproveitar das restrições sobre a análise marxista para desqualificar e condenar como 
comunista o compromisso com a causa dos pobres. O diálogo deve ser cultivado. É imprescindível para a emancipação dos pobres e para o cuidado da casa comum. Obras que dissecam o capitalismo e sua dinâmica, como é o caso de Marx, são bem-vindas. O marxismo, utilizado como mediação para o discurso da ética teológica, ajuda a esclarecer conceitos centrais teologia moral.

Marxismo e Doutrina Social da Igreja continuam atuais nestes tempos de proletariado da era digital da Quarta Revolução Industrial. O capitalismo selvagem, semelhante ao da primeira Revolução Industrial, que originou o marxismo e a DSI, voltou com toda força. A desumanização do trabalho é sua dimensão mais cruel. Os trabalhadores, cada vez mais desprotegidos, vivem um momento extremamente dramático. Marx e DSI nos ajudam a manter o otimismo em tempos difíceis e a ter esperança. A história se faz com os mais pobres. Para preservar a fidelidade às suas próprias tradições, DSI e Marxismo precisam manter-se inabaláveis em sua visão profundamente crítica do capitalismo. A humanidade e a criação precisa deles. "Ninguém pode sentir-se exonerado da preocupação pelos pobres e pela justiça social" (EG, 201). Nem marxistas, nem cristãos.

\section{Referências bibliográficas}

ARENAS POSADAS, C. Historia económica del trabajo: siglos XIX y XX. Madrid: Tecnos, 2003.

ARRUPE, Pedro. "Análise marxista". Coleção Ignatiana, 1981, n. 17.

BENTO XVI, Papa. Encíclica Caritas in Veritate. Sobre o desenvolvimento humano integral na caridade e na verdade. Roma: Libreria Editrice Vaticana, 2009.

BENTO XVI, Papa. Encíclica Deus caritas est. Roma: Libreria Editrice Vaticana, 2005.

BOFF, Clodovis. Teologia e prática. Teologia do político e suas mediações. Petrópolis: Vozes, 1978.

BORDIN, Luigi. O Marxismo e a Teologia da Libertação. Rio de Janeiro: Dois Pontos, 1987.

CALVEZ, Jean-Yves. El pensamiento de Carlos Marx. Madrid: Taurus, 1966.

Carta de Marx e Engels a Bebel 1879 - In: MARX, Karl, y ENGELS, Friedrich. Correspondéncia. Cartago: Buenos Aires, 1973.

CASTEL, Robert. Las metamorfosis de la cuestión social. Una crónica del salariado. Barcelona: Paidós, 1997.

CONCÍLIO VATCANO II. Constituição Pastoral Gaudium et spes. Sobre a Igreja no mundo contemporâneo. Roma: Libreria Editrice Vaticana, 1965. 
CONGREGAÇÃO PARA A DOUTRINA DA FÉ; DICASTÉRIO PARA O SERVIÇO DO DESENVOLVIMENTO HUMANO INTEGRAL. Oeconomicae et pecuniariae quaestiones: considerações para um discernimento ético sobre alguns aspectos do atual sistema econômico-financeiro, 2018. Roma: Libreria Editrice Vaticana, 2013.

ENGELS, Friedrich. Contribuição para a história do cristianismo primitivo (1895). Rio de Janeiro: Laemmert, 1972.

FRANCISCO, Papa. Exortação Apostólica Evangelii Gaudium (EG). Roma: Libreria Editrice Vaticana, 2013.

. I Encontro Mundial de Movimentos Populares. Disponível em: <https:// w2.vatican.va/content/francesco/pt/speeches/2014/october/documents/papa-francesCo_20141028_incontro-mondiale-movimenti-populari.html>. Aceso em: 15/04/2019.

. II Encontro Mundial de Movimentos Populares. Disponível em <https:// w2.vatican.va/content/francesco/pt/speeches/2015/july/documents/papa-francesco_20150709_bolivia-incontro-mondiale-movimenti-populari.html>. Aceso em: $15 / 04 / 2019$.

. III Encontro Mundial dos Movimentos Populares. Disponível em <http:// w2.vatican.va/content/francesco/pt/speeches/2016/november/documents/papa-francesco_20161105_movimenti-popolari.html>. Acesso em: 15/03/2019.

GARAUDY, Roger. Do Anátema ao diálogo. Rio de Janeiro: Paz e Terra, 1966.

GASDA, Élio. Dimensão ético-social: memória subversiva de um Deus Crucificado: Rev. Pistis Praxis Teologia E Pastoral (Curitiba), v. 10, n. 2, 2018, p. 269-289.

. Política, Cristianismo e laicidade: Perspectiva Teológica (Belo Horizonte), v. 47, n. 132,2015 , p. 203-220.

Essa economia mata (EG, 53). Crítica teológica do capitalismo inviável: Rev. Perspectiva Teológica, vol. 49, n. 3, 2017, p. 573-578.

GIANSOLDATI, Franca. Jornal Il Messaggero, Roma, 29-06-2014. Tradução Moisés Sbardelotto. Disponível em: <http://www.ihu.unisinos.br/noticias/532796-o-comunismo-nos-roubou-a-bandeira-entrevista-com-o-papa-francisco>. Acesso em 18/03/2019.

JOÃO PAULO II, Papa. Encíclica Centesimus annus. Roma: Libreria Editrice Vaticana, 1991.

. Encíclica Laborem exercens. Sobre o exercício do trabalho. Roma: Libreria Editrice Vaticana, 1981.

. Encíclica Sollicitudo rei socialis. Roma: Libreria Editrice Vaticana, 1987.

LEÃO XIII, Papa. Encíclica Rerum novarum. Roma: Librería Editrice Vaticana, 1891.

LEHMANN, Paul. 1966. "Ética cristã, ética marxista". Revista Paz e Terra, 1: Rio de Janeiro: Paz e terra, julho, 1966.

LOCKE, John. Segundo Tratado del Gobierno Civil (1690). Madrid: Alianza, 1990.

MARX, Karl. Trabajo asalariado y capital (1891). Madrid: R. Aguillera, 1968.

. Crítica da Filosofia do Direito de Hegel (1843). São Paulo: Boitempo, 2013.

. Manuscritos económicos y filosóficos (1844). Moscú: Progreso, 1989. 

tural, 1985.

O Capital: crítica da economia política (1867). 2ª ed. São Paulo: Nova Cul; ENGELS, Friedrich. La Ideología alemana (1845). Barcelona, L’Eina, 1988.

PALÁCIO, Carlos. (org.). Cristianismo e história. São Paulo: Loyola, 1982.

PARIAS, Louis-Henri (dir.). Historia general del trabajo. La era de las revoluciones (1760-1914). México: Grijalbo, 1965.

PAULO VI, Papa. Carta apostólica Octogesima adveniens. Roma: Libreria Editrice Vaticana, 1971.

PIO XI, Papa. Enciclica Divini Redemptoris - Sobre o comunismo ateu. Roma: Libreria Editrice Vaticana, 1937.

Carta encíclica Quadragesimo Anno. Roma: Libreria Editrice Vaticana, 1931.

POLANYI, Karl. La gran transformación. Madrid: La Piqueta, 1989.

PONTIFICIO CONSELHO JUSTIÇA E PAZ. Compendio da Doutrina Social da Igreja (CDSI) São Paulo: Paulinas, 2005.

SMITH, Adam. La riqueza de las naciones (1776). Madrid: Aguilar, 1961.

STEDMAN JONES, Gareth. Karl Marx. Grandeza e ilusão. Tradução de Berilo Vargas. São Paulo: Companhia das Letras, 2017.

Endereço do Autor:

Av. Dr. Rubens Guimarães, 2.127

Bairro Planalto

31720-300 Belo Horizonte - MG

gasdasj@hotmail.com 